\title{
PROPRIETARY ESTOPPEL AND PROPERTY RIGHTS
}

\author{
Susan Bright ANd Ben McFarlane*
}

\section{INTRODUCTION}

THIS article focuses on a particular aspect of the operation of proprietary estoppel: it asks when a proprietary estoppel claim will give rise to a property right. The inquiry proceeds on the linked assumptions that proprietary estoppel is a means of acquiring rights and that rights thereby arising take effect immediately, without the need for any court order. ${ }^{1}$ Like any other means of acquiring rights, proprietary estoppel can give rise either to personal rights or to property rights: in some cases the estoppel claimant is acknowledged to have a personal right (e.g. to damages ${ }^{2}$ or a licence to use $\left.\operatorname{land}^{3}\right)$; in others a property right (e.g. a lien; ${ }^{4}$ an easement $;^{5}$ a lease $;^{6}$ or a freehold $\left.{ }^{7}\right)$. The central argument of this article is that proprietary estoppel should give rise to a property right only if that is necessary to protect the claimant's reasonable reliance. Where a personal right gives sufficient protection that will have to do, whatever the claimant may have been promised or expected; this may well mean that the circumstances in which a property right arises are more narrow than has been thought. The premise on which this argument rests is that, consistently with the law's clear desire to contain the situations in which property rights arise, ${ }^{8}$ a claim should give rise to a property right only if that is demanded by the principle underlying that claim. It is therefore vital to explain the principle that underpins the doctrine of proprietary estoppel and to provide further principles which will

\footnotetext{
* New College Oxford and Trinity College Oxford.

1 B. McFarlane, "Proprietary Estoppel and Third Parties after the Land Registration Act 2002" [2003] C.L.J. 661.

2 e.g. Jennings v. Rice [2003] 1 P. \& C.R. 100.

3 e.g. Parker v. Parker [2003] EWHC (Ch.) 846

4 e.g. Campbell v. Griffin (2001) EWCA Civ. 990, (2001) 82 P. \& C.R. (D) 23.

5 e.g. Crabb v. Arun D.C. [1976] Ch. 179.

6 e.g. Griffiths v. Williams [1978] 2 E.G.L.R. 121.

7 e.g. Pascoe v. Turner [1979] 1 W.L.R. 431.

${ }^{8}$ Contained because of the fact that the advantages inherent in property rights necessarily confer burdens on other users of the property: see, for example, the approach in Hill v. Tupper (1863) 2 H. \& C. 121 and Westdeutsche Landesbank Girozentrale v. Islington LBC [1996] A.C. 669.
} 
enable parties and courts to judge when an estoppel claimant has acquired a property right and when a merely personal right. ${ }^{9}$

Some may think that a search for such principles will be both futile and inappropriate. Futile as the broad discretion that characterises proprietary estoppel cannot be adequately described by specific principles; inappropriate because the flexibility of the doctrine should not be circumscribed. Neither claim is accepted. There are sound reasons why the operation of proprietary estoppel should be governed by a closely structured discretion. The basic imperative of treating like cases alike requires that the specific factors which guide a court's decision be identified. It simply will not do to say that because the underlying purpose of estoppel is to "prevent unconscionability" the judge in each case has an openended discretion. Further, as in any area of law, the greater certainty conferred by elaborating specific principles lessens the risk of extensive and costly litigation. Certainty is at a premium in this particular context as third parties dealing with the land will need to know if the estoppel claimant has acquired a property right in that land. Moreover, as section 116(a) of the Land Registration Act 2002 confirms that rights arising through estoppel can take effect before an order of the court, it is no longer possible to argue that rights arising through estoppel should be determined on a discretionary basis and only have effect after a court order declaring their existence. ${ }^{10}$ It is therefore crucial that the principles underlying the acquisition of rights through proprietary estoppel be brought to the fore.

It will therefore be argued that proprietary estoppel is endowed with no more discretion than any other equitable source of rights. Although much academic thinking and judicial dicta suggest otherwise, emphasizing the discretionary nature of estoppel, the principles discussed below are drawn from, and hence consistent with, the vast majority of case-law. Similarly, the claim that a property right should exist only if necessary to protect the claimant's reasonable reliance, whilst novel, is consistent with not only the law's general desire to contain the incidence of property rights but also the outcomes in much of the case-law on proprietary estoppel. ${ }^{11}$

\footnotetext{
${ }^{9}$ Similar debates as to whether and when a particular source of rights can give rise to property rights occur in the context of unjust enrichment and the law of wrongs: see, for example, P. Birks, Unjust Enrichment (Oxford 2003), ch. 8; P. Millett, "Bribes and Secret Commissions" [1993] R.L.R. 7

10 This was Hayton's argument in "Equitable Rights of Cohabitees" [1990] Conv. 370 and "Constructive Trusts of Homes - a Bold Approach" (1993) 109 L.Q.R. 485.

11 There are cases in which courts have been too ready to recognise a property right; these are discussed later in the article under the heading "Proprietary Overkill": see Part IV, section B3.
} 
In what follows $\mathrm{A}$ is the owner of land; $\mathrm{B}$ is the person who reasonably relies upon an expectation, for which $\mathrm{A}$ is responsible, that he has or will acquire some right in relation to A's land; and $\mathrm{C}$ is the transferee of A's land. In essence it is argued that:

1. Proprietary estoppel is an event which gives rise to rights without the need for an order of the court; it does not simply enable B to be a "supplicant seeking the exercise of a discretion in his favour". ${ }^{12}$

2. Proprietary estoppel always gives $\mathrm{B}$ a personal right against $\mathrm{A}$, and this right will continue even if $\mathrm{A}$ transfers the land to which B's expectation relates to $\mathrm{C}$. $^{13}$

3. The extent of B's right will be guided by the need to protect B's reasonable reliance on the expectation for which $\mathrm{A}$ is responsible and will be governed by the principle of proportionality. This principle demands that B's right is the minimum response necessary to protect B's reasonable reliance. The court's determination of that right is constrained by principle and is not simply a matter of intuitive justice.

4. Proprietary estoppel may also give B a property right, enforceable in the usual way, but only when this is necessary to protect B's reliance.

5. If B's right is threatened, then B may go to court to seek a remedy. The court will then decide on an appropriate remedy to protect B's right; the exercise of the court's discretion at this stage may involve a wider range of factors than are relevant in determining B's right. As when making any order, the court will take into account circumstances prevailing at the time of the order. This is no different from the discretion exercised whenever a court has to decide how to protect B's equitable right, however it has arisen.

In order to substantiate these arguments, the first task is to identify the principle which motivates the recognition of proprietary estoppel claims (Part 2) and then to describe the protection afforded to $\mathrm{B}$ if he is left with a merely personal right (Part 3). This sets the scene for examining the central question of when

12 This phrase is used by Birks to explain how "discretionary remedialism" does not permit of B's having rights: P. Birks, "Three Kinds of Objection to Discretionary Remedialism" (2000) 29 U. Western Australia L. Rev 1 at 13. Compare K. Gray \& S. Gray, Elements of Land Law, 4th ed. (Oxford 2004), at p. 968: a successful estoppel claimant has an entitlement "to bend the ear of the court of conscience to listen sympathetically to his plea for a restraint upon the landowner's exercise of his rights."

13 This point is argued more fully in Bright and McFarlane, "Personal Liability in Proprietary Estoppel" [2005] Conv. 14. 
proprietary estoppel should additionally lead to a property right (Part 4). The picture will then be completed by analysing the remedy $\mathrm{B}$ may receive to give effect to a right arising through proprietary estoppel (Part 5).

\section{The Basis of Proprietary Estoppel}

In order to determine the nature and extent of rights arising through proprietary estoppel it is crucial to ask why proprietary estoppel is recognised as a source of rights. Any account of the underlying purpose of the doctrine must be consistent both with the test for the availability of a proprietary estoppel claim, and with the extent of the rights awarded in response to such a claim. In particular cases proprietary estoppel may have the effect of allowing the informal grant of a property right; of enforcing a promise; or of reversing an unjust enrichment. Yet none of these three aims can constitute the basic purpose of the doctrine as, by itself, each fails to account both for the test for the availability of a claim and for the extent of the rights thereby gained by B. ${ }^{14}$

On this approach, the only satisfactory theory of proprietary estoppel is one which explains proprietary estoppel as generating rights in order to protect B's reliance. Analysis of the case law shows that proprietary estoppel is concerned with reacting to and protecting B's reasonable reliance, where A can be said to be responsible for the expectation on which that reliance was based. This particular form of reliance seems to be the unifying feature which justifies the courts' view of proprietary estoppel as a single doctrine. $^{15}$

Moreover, this aim of protecting B's reliance explains the diverse range of responses to a proprietary estoppel claim. It does not follow that protecting reliance will limit $\mathrm{B}$ to recovering the direct financial cost of his reliance. This is no surprise: the reliance B needs to show in order to bring a claim is not limited to

\footnotetext{
${ }^{14}$ Moriarty's view that estoppel is a mechanism for the "informal creation of proprietary rights in land" cannot explain cases where B has a non-proprietary expectation, nor those where B is awarded a personal right after reliance on a proprietary promise (S. Moriarty, "Licences and Land Law" (1984) 100 L.Q.R. 376). Birks' view that estoppels are "binding promises" cannot explain cases where A does not make a promise, nor those where a promise made by A is not enforced (P. Birks 'Equity in the Modern Law: An Exercise in Taxonomy' (1996) 26 U. Western Australia L. Rev 1 at 60). Similarly, proprietary estoppel cannot be seen as having the aim of reversing unjust enrichment as suggested by Goff and Jones: a remedy may exist even if A is not unjustly enriched; and even if he is, B's right may not be measured by the unjust enrichment (Lord Goff and G. Jones, The Law of Restitution, 6th ed., by G. Jones (London 2002), at pp. 230-235).

15 The fact that the reliance is on an expectation that B has or will acquire a right in relation to A's land also distinguishes proprietary estoppel from other types of estoppel, such as promissory estoppel.
} 
financial expenditure; ${ }^{16}$ hence the reliance protected by B's consequent right is not so limited. This can be seen in Crabb v. Arun District Council. ${ }^{17}$ B's reliance in that case consisted of selling part of his land without reserving a right of access to his remaining land. Were A then able to deny B his expected easement over A's land, B would be left without access to that remaining land. That particular reliance could only be protected by allowing B to have the expected easement over A's land. In some cases, protecting B's reliance will require B's receiving a property right through an informal grant; in others it will require the enforcement of a promise by $\mathrm{A}$; in others the reversal of A's unjust enrichment; in others the reimbursement of money spent by B. In each case, however, each response will not be a goal in itself but will rather be a means to the end of protecting B's reliance.

The suggestion that the basic function of proprietary estoppel is to protect B's reliance is not novel. Drawing largely on Australian case-law, Robertson and Spence have both developed similar, but differing, accounts of a general estoppel doctrine (extending beyond proprietary estoppel) which is centred around the need for A to take responsibility for the protection of B's reliance. ${ }^{18}$ This certainly does not mean that there is any consensus as to the purpose of proprietary estoppel as applied in the Australian courts, ${ }^{19}$ but it may be significant given the English courts' recent use of proportionality in assessing the appropriate response to a proprietary estoppel claim. In Sledmore v. Dalby, Hobhouse L.J. drew extensively on the judgment of Mason C.J. in Commonwealth of Australia v. Verwayen, ${ }^{20}$ noting in particular the statement that: "A central element of [estoppel] is that there must be a proportionality between the remedy and the detriment which is its purpose to avoid. It would be wholly inequitable and unjust to insist upon a disproportionate making good of the relevant assumption." 21

The use of proportionality in recent English decisions supports the view that the purpose of proprietary estoppel is to protect B's reliance: making a proportionate award, like finding the "minimum equity to do justice to $[\mathrm{B}]$ ", ${ }^{22}$ entails recognizing that $\mathrm{B}$ has a right

${ }^{16}$ Gillett v. Holt [2000] 2 All E.R. 289.

17 [1976] Ch. 179.

18 A. Robertson, "Towards a Unifying Purpose for Estoppel" (1996) 22 Monash U L Rev 1; "Situating Equitable Estoppel Within the Law of Obligations" (1997) 19 Sydney L Rev 32; Reliance and Expectation in Estoppel Remedies" (1998) 18 Legal Studies 360. M. Spence, Protecting Reliance: The Emerging Doctrine of Equitable Estoppel (Oxford 1999).

19 For a contrary view see e.g. J. Edelman, "Remedial Certainty or Remedial Discretion in Estoppel After Giumelli?" (1999) 15 J.C.L. 179.

20 (1990) 170 C.L.R. 394.

21 (1996) 72 P \& C.R. 196 at 208-209.

22 per Scarman L.J. in Crabb v. Arun D.C. [1976] Ch. 179 at 198. 
which adequately protects his reliance, but goes no further. The application of this principle in practice can be seen by a consideration of Jennings v. Rice ${ }^{23}$ and Ottey v. Grundy. ${ }^{24}$ In Jennings v. Rice, B spent a considerable amount of time looking after $\mathrm{A}$ but was paid nothing. When challenged about her failure to pay him, A said something to the effect that "this will all be yours one day". B's expectation was - at the minimum - of the house and furniture worth $£ 435,000$, and - at the maximum - of the entire estate worth $£ 1.285$ million. The actual award was $£ 200,000$, based on the cost of equivalent full-time nursing care for A. The facts of Ottey v. Grundy were somewhat unusual as A and B had reached an explicit agreement about what property $B$ should receive in the event of A's death: the plan was for B to receive a life interest in a houseboat, valued at $£ 240,000$ to $£ 250,000$, plus an apartment. However, when A died three years later, the necessary formalities had not been completed. Judge Langan Q.C. noted that the expectation was wholly out of proportion to the detriment $\mathrm{B}$ had incurred in reliance on the agreement and awarded the much lesser sum of $£ 50,000$ plus the apartment. Hence, even if $\mathrm{A}$ has made a very clear promise, enforcing B's expectation will not always be the appropriate or proportionate response to the estoppel.

It is possible to take the results in Jennings and Ottey as evidence of the wide discretion a court has when responding to an estoppel claim. ${ }^{25}$ Certainly, there is a tendency to equate the move away from the automatic enforcement of expectations with a move towards the courts having discretion to react to a proprietary estoppel as they see fit and even to re-distribute property rights. ${ }^{26}$ However, as discussed above, it is preferable to find specific principles which can be used to regulate that task: even when departing from expectations a court must, as Robert Walker L.J. emphasised in Jennings v. Rice, "take a principled approach". ${ }^{27}$ Admittedly, protecting B's reliance is a less predictable standard than routinely enforcing B's expectation: there will always be an element of judgment in gauging what is proportionate. The matter will not, however, be left to the unbridled discretion of the court: the crucial point is that the response to the estoppel will be guided by the goal of protecting B's reliance.

${ }^{23}$ [2003] 1 P. \& C.R. 100.

24 [2003] EWCA Civ. 1176.

${ }^{25}$ See e.g. M. Thompson [2004] Conv. 137.

${ }^{26}$ See e.g. C. Rotherham, Proprietary Remedies in Context (Oxford 2002), esp. at pp. 33-42 and 296-297.

27 [2003] 1 P. \& C.R. 100 at [43]. 


\section{Personal Liability in Proprietary EstopPel}

It is clear that the proportionate response to a proprietary estoppel claim may be the recognition that $\mathrm{B}$ has a personal right against $\mathrm{A}$, rather than a property right. $^{28}$ In such cases, $\mathrm{B}$ is at risk if $\mathrm{A}$ transfers the relevant land to $\mathrm{C}$ : the personal right $\mathrm{B}$ has acquired through the estoppel cannot bind $\mathrm{C}$. There is no reason, however, why B should not still be able to assert his personal right against A: A's liability to B should not end simply because of the transfer to $\mathrm{C} .{ }^{29}$ Imagine, for example, that in Jennings v. Rice A had transferred the property to $\mathrm{C}$ during her lifetime but after $\mathrm{B}$ had relied on A's assurances that it would be his. There is no reason to think this variation would prevent B's asserting his personal right against A and thereby gaining $£ 200,000$ : the need to protect B's reliance would remain.

It can therefore be argued that proprietary estoppel, like wrongs, unjust enrichment and other non-consensual sources of rights, always gives rise to an underlying personal liability which may, in some circumstances, be coupled with a property right. As A's personal liability will persist after a transfer of the land in respect of which the proprietary estoppel claim arose, it may well be that $\mathrm{B}$ has no need of a property right to protect his reliance: instead B is adequately protected through his personal right against A. In Beale v. Harvey, ${ }^{30}$ for example, A divided some disused farm buildings into building plots and exchanged contracts to sell plot 1 to B whilst retaining plot 2. Before completion, but with A's consent, B began to landscape her garden and improve the fencing. Unknown to both parties at that stage there had been a mistake made by $\mathrm{A}$ in marking out the boundary: the boundary fence included as part of plot 1 land that was in fact part of plot 2. The sale to B was completed and the mistake emerged only later, after $\mathrm{C}$ had contracted to buy plot 2 from A. Once the mistake had come to light, A offered to move the boundary fence to the correct position and to compensate $\mathrm{B}$ for any disturbance this caused. B refused to agree to this and instead claimed that A was estopped from moving the boundary fence and that this estoppel bound $\mathrm{C}$ by virtue of the Land Registration Act 1925, section 70(1)(g). The Court of Appeal disagreed. Lord Justice Peter Gibson observed that B had suffered "too insubstantial a detriment to make it

${ }^{28}$ See e.g. Jennings v. Rice [2003] 1 P. \& C.R. 100.

${ }^{29}$ For a discussion of relevant authority, see Bright and McFarlane, "Personal Liability in Proprietary Estoppel" [2005] Conv. 14 at 19-23. Indeed, it is argued there that A's personal liability will survive a transfer to $\mathrm{C}$ not only when $\mathrm{B}$ has a (mere) personal right but even when $\mathrm{B}$ has a property right. This is important as B may be unable to enforce his property right against C, as in Lloyd v. Dugdale [2002] 2 P. \& C.R.13.

30 [2003] EWCA Civ. 1883. 
unconscionable for $[\mathrm{A}]$ to seek to rectify its mistake at its own expense." ${ }^{31}$ Allowing B ownership of the disputed land would be a disproportionate response to the estoppel. Put quite simply, the extent of B's reliance did not justify the award of a property right; rather, B would be adequately recompensed by A's offer to bear the costs of the disturbance. ${ }^{32}$ It is thus clear that the recognition of a persisting personal liability on A's part may be a proportionate response to a proprietary estoppel claim, even in a case where the land has been transferred to $\mathrm{C}^{33}$

\section{Proprietary Estoppel and Property Rights}

This article focuses on the question of when B should acquire a property right in addition to the underlying personal right against A. Property rights should arise only when this is demanded by the principle underlying the particular source of the right in question. ${ }^{34}$ Hence proprietary estoppel should only give rise to a property right if a personal right is inadequate to protect B's reliance. The first part of this section is therefore an examination of the principles which determine how B's reliance is to be protected. The second part then determines if the application of these principles necessitates B's acquiring a property right. This is done by identifying the advantages that flow from having a property right as opposed to a purely personal right and asking if $\mathrm{B}$ needs those advantages in order for his reliance to be fully protected.

\section{A. Protecting B's Reliance: Basic Principles}

\section{All cases: B's right cannot exceed his expectation}

It will never be a proportionate response for B to get more than he was expecting. ${ }^{35}$ As B's reliance is premised on his expectation, B can never claim that a greater right is necessary to protect that

31 Ibid. at [39].

${ }^{32}$ As A had offered to re-imburse B, Beale does not provide definite authority for A's being under a persisting personal obligation.

33 This necessarily casts doubt on the interpretation of the Land Registration Act 2002, s. 116(a) favoured by the Law Commission and criticised by McFarlane, "Proprietary Estoppel and Third Parties after the Land Registration Act 2002" [2003] C.L.J. 661 at 688-696 and by the editors of Snell's Equity, 31st ed., by J. McGhee, (London 2005), at p. 289.

${ }^{34}$ This principle is discussed in J. Edelman, Gain-Based Damages: Contract, Tort, Equity and Intellectual Property (Oxford 2002) at 258-264. See too A.S. Burrows, "Proprietary Restitution: Unmasking Unjust Enrichment" (2001) 117 L.Q.R. 412 at 424-428.

35 Burrows \& Burrows v. Sharp (1989) 23 H.L.R. 82 at 92: "In general [the court] would, if possible, want to avoid giving the claimant more than he was ever intended to have". Crabb v. Arun D.C. is sometimes said to involve B's getting more than expected as the easement was granted to B without payment, but this is better understood as representing compensation for A's interference with B's easement: see S. Gardner, "Remedial Discretion in Proprietary Estoppel" [1999] 115 L.Q.R. 438 at 445 and McFarlane, "Proprietary Estoppel and Third Parties after the Land Registration Act 2002" [2003] C.L.J. 661 at 674-675. 
reliance. Dodsworth v. Dodsworth ${ }^{36}$ provides a good illustration: B1 and B2 spent a sum of money improving A's bungalow in the expectation that they would be able to live there, with A, for as long as they wished. The Court of Appeal could not see a way of protecting the occupation of B1 and B2 without creating a life interest under the Settled Land Act. However, as it would lead to B1 and B2's acquiring a "greater and more extensive interest than was ever contemplated", ${ }^{37}$ this solution was not adopted.

Given that expectations set a cap on B's right, it is clear that B should not acquire a property right through estoppel if he expected some lesser right. Careful attention must therefore be given to the question of whether B's expectation falls within the group of recognised property rights in land. This is particularly relevant in cases where B expects "a roof over his head". In land law the choices for an occupational right are clear: if it is a property right it must be either a freehold estate (sole or, if shared, behind a trust of land) or a lease; otherwise it must be a licence, a personal right enforceable only against A.

Of course, A and B are unlikely to have thought in such terms: it is for the law to put a form on the substance of their expectations. The first question is whether B expected ownership, be it indefinitely (freehold) or for a limited period (leasehold) ${ }^{38}$ be it sole $^{39}$ or shared. ${ }^{40}$ In many cases, B's expectation involves sharing occupation with $\mathrm{A}$, and hence the right $\mathrm{B}$ expects is unlikely to involve exclusive possession of any part of A's land. If it is also clear that a share of the freehold is beyond B's expectation then, as in Dodsworth v. Dodsworth, ${ }^{41}$ B's expectation will, at most, amount to an indefinite licence. ${ }^{42}$ In such a case, it will be impossible for the proprietary estoppel claim to give rise to a property right.

Hence, as B's expectation forms a cap to his estoppel claim, B's ability to fit that expectation within the class of property rights is a

36 (1973) 228 E.G. 1115.

37 per Russell L.J. at 1115. See too Baker v. Baker [1993] 2 F.L.R. 247 at 251, per Dillon L.J.

38 In some cases it will not be immediately clear whether B's expectation was of a freehold or a leasehold: see e.g. Inwards v. Baker [1965] 2 Q.B. 29.

39 See e.g. Pasoce v. Turner [1979] 1 W.L.R. 431; Ottey v. Grundy [2003] EWCA Civ. 1176.

40 Lloyds Bank v. Rosset [1991] 1 A.C. 107. In practice, this has become a specialised area with its own set of rules: if not express, the assurance can be nonetheless be inferred from B's conduct (per Lord Bridge at 132-133); and the appropriate response takes account of the entire course of dealing between A and B, not simply A's assurances and B's reliance: see e.g. Midland Bank v. Cooke [1995] 4 All E.R. 562. However, if the courts are to take seriously the suggestion in Oxley v. Hiscock [2004] EWCA Civ. 546 that the extent of B's rights in such a case should be governed by principles derived from proprietary estoppel, then it is submitted that the structure set out in this article may usefully be applied.

41 (1973) 228 E.G. 1115.

42 See the view that "rights requiring active cooperation and mutual trust and confidence between the right-holder and the landowner cannot be property rights": S. Bright, "Of Estates and Interests" in S. Bright \& J. Dewar (eds.) Land Law: Themes and Perspectives (Oxford 1998), at p 541. 
necessary condition of B's acquiring a property right through the estoppel. However, it must be emphasised that it is by no means a sufficient condition-B will still need to demonstrate that his reliance can only be adequately protected by means of a property right.

\section{2. "Bargain Cases": B's expectation is protected if B performs an agreed quid pro quo}

In cases where A promises a defined right in return for particular, clearly defined action by B (bargain cases) then, if B fully performs his side of the bargain, the court will protect B's expectation. Until then, $\mathrm{A}$ is free to withdraw the assurance and $\mathrm{B}$ will have a right that protects his reliance to date, taking account of the original assurance. Once reliance is complete, however, the proportionate response will almost always ${ }^{43}$ be to enforce the bargain (but not necessarily in specie). ${ }^{44}$ Proportionality is assured because A and B have ascribed particular value to B's reliance and $\mathrm{B}$ has done exactly what A agreed or suggested was necessary in order to acquire the promised right. $^{45}$ As Robert Walker L.J. noted in Jennings v. Rice, enforcing the expectation will be neither an excessive response to B's reliance, nor a disproportionate burden upon A: "the consensual element of what has happened suggests that the claimant and the benefactor probably regarded the expected benefit and the accepted detriment as being (in a general, imprecise way) equivalent, or at any rate not obviously disproportionate." $" 46$

Case law provides many illustrations of this "bargain" principle. ${ }^{47}$ In Voyce v. Voyce B was promised a cottage by his mother, A, "provided he did it up to his mother's satisfaction"; after completion of the work the court recognised that B was the equitable owner. ${ }^{48}$ Singh v. Sandhu is described by Balcombe L.J. as a "quid pro quo" case: B was encouraged to put up a garage on A's land in return for an exchange of land, and was recognised as the fee simple owner of the land on which the garage was built. ${ }^{49}$

\footnotetext{
${ }^{43}$ Subject to proportionality performing a minor role where the extent of the requested reliance is not clearly set in advance and there is, as it turns out, a great disparity between expectation and reliance: see the discussion of promises to provide life-long care, text below from n. 52 .

${ }_{44}$ As to whether an in specie remedy will be available, see Parts $4 \mathrm{~B}$ and 5 , below.

${ }^{45}$ Indeed, reimbursing the costs incurred by $\mathrm{B}$ in performing his side of the bargain will be an inadequate response as it will fail to take account of the parties' perception of "the balance of risks and rewards" to B of performing his side of the bargain: see Etherton $\mathrm{J}$. in Cobbe v. Yeoman's Row Management Ltd. [2005] EWHC 266 (Ch) at [136].

46 [2003] 1 P. \& C.R. 100 at [45].

47 Other examples include Kinane v. Mackie-Conteh [2005] EWCA Civ. 45, Yaxley v. Gotts [2000] Ch. 162 (discussed below, text from n. 88) and Siew Soon Wah v. Yong Tong Hong [1973] A.C. 836 .

48 (1991) 62 P. \& C.R. 290.

49 unrep. May 4th 1995, CA
} 
Likewise in Baker v. Baker B paid $£ 33,950$ to help A1 and A2 buy a house in return for a right, living as part of the family, to occupy the granny room rent-free for the rest of his life and it was this right that set the value of B's award. ${ }^{50}$

There are, of course, some similarities between these cases and the operation of contract law. B's reliance seems to mimic the role of consideration in ensuring the enforceability of B's expectation. These bargain cases are not, however, simply instances of contract law at work. First, in these cases, the agreement is usually not enforceable as a contract because of the absence of necessary formalities. ${ }^{51}$ Secondly, whereas a contractual promise is binding from the moment of agreement, in these estoppel cases $\mathrm{A}$ is free to withdraw his assurance unless and until B has completed his side of the bargain. If $\mathrm{B}$ has begun to rely on the assurance, then he will have an estoppel claim against $\mathrm{A}$ but this will only entitle him to a right necessary to protect his reliance to date and will not guarantee enforcement of B's expectation. ${ }^{52}$ Thirdly, it may be that proportionality does have a minor role to play if B's expectation greatly exceeds his reliance. This might occur in cases where the reliance consists of performance for an indefinite time and, as events turn out, the end date occurs sooner than the parties envisaged (or wanted). In Jennings v. Rice reliance consisted of B's caring for A and Aldous L.J. posited the following question: "If ... A had died one month, one year or twenty years after making the representation relied on, should the court award the same sum?",53 Jennings itself is not a bargain case as the assurance was uncertain, but if there were a clear bargain of a house in return for life-long care and A were to die very shortly after this promise it is unlikely that the court would consider enforcement of such a bargain appropriate. In cases where the value of the reliance is fixed (such as the renovation of the cottage in Voyce v. Voyce $)^{54}$ it will not be for the court to second guess whether the bargain itself is proportionate, but where the value of the reliance cannot be known at the outset because it depends on unpredictable future events it is

${ }^{50}$ [1993] 2 F.L.R. 247. In the event, although B's expectation set the extent of his right, he was unable to enjoy the right in specie. This is discussed further below, text at $\mathrm{n}$. 114 .

${ }^{51}$ If the agreement involves the creation of a property right, then it will only be contractually enforceable if it complies with the requirements of the Law of Property (Miscellaneous Provisions) Act 1989, s. 2.

52 The estoppel situation thus differs from that of a unilateral contract. Where there is a unilateral contract, if $\mathrm{A}$ withdraws a promise as $\mathrm{B}$ is attempting to perform the condition necessary to enforce that promise, A will be in breach of contract. The standard view (set out but queried by G.H. Treitel, The Law of Contract, 11th ed. (London 2003), at p. 41) is that B can then claim damages reflecting his expectation. On some facts, both an estoppel and a unilateral contract analysis may be possible: see Errington v. Errington [1952] 1 K.B. 290.

53 [2003] 1 P. \& C.R. 100 at [37].

54 (1991) 62 P. \& C.R. 290. 
open to the court not to enforce the bargain if, as things turn out, B's expectation is out of all proportion to his reliance. ${ }^{55}$

\section{3. "Agreed Interest Cases": B's expectation will be protected if B} relies on $A$ 's assurance that there is a binding agreement between $A$ and $B$, under which $A$ is to grant $B$ a right in return for payment

In the preceding section, cases "like a contract" were discussed where the usual defect preventing contractual enforcement is the absence of the requisite formalities. There is also a category of cases, again similar to contract, where the defect is that the contractual agreement has not been finalised, let alone formalised: a right is being negotiated between $\mathrm{A}$ and $\mathrm{B}$, the parties have reached an agreement in principle, ${ }^{56}$ and some further conduct by A leads B reasonably to believe that $\mathrm{A}$ will honour that agreement, notwithstanding the fact that it is not, in itself, legally binding. ${ }^{57}$ Where $\mathrm{A}$ and $\mathrm{B}$ have agreed all material terms governing the grant of the right including the consideration that $\mathrm{B}$ will provide in return, an act by B that shows that he is relying upon A's assurance that their agreement will be honoured is likely to lead to enforcement of his expectation. ${ }^{58}$ This prevents A's relying on the "usual commercial position" that there is no binding agreement.

In these cases, B's reliance is closely interwoven with A's assurance. In Lloyd v. Dugdale ${ }^{59} \mathrm{~A}$ and B were negotiating a lease. $\mathrm{B}$ urgently needed to relocate his business and agreed to take a long lease of A's property, which needed restoring. B was concerned that it would be unwise to spend money on A's property until things were tied up. Reassured by A's comments that he was a "man of his word" and "not to worry", B spent substantial sums on the property, effectively becoming "locked in" 60 to this particular property and losing the opportunity to buy premises elsewhere. Against this background the Court of Appeal recognised that A would be under an obligation to grant B the agreed lease. In $J T$ Developments v. Quinn ${ }^{61}$ the Court of Appeal was troubled by

${ }_{55}^{55}$ Compare Ottey v. Grundy [2003] EWCA Civ. 1176.

${ }^{56}$ Where there are important terms outstanding the court has been unable to find an estoppel: Pridean Ltd. v. Forest Taverns Ltd. (1998) 75 P \& CR 447; Orgee v. Orgee [1997] E.G.C.S. 152; Willis v. Hoare, unrep. December 3rd 1998, C.A.

${ }^{57}$ See e.g. Cobbe v. Yeoman's Row Management Ltd. [2005] EWHC $266(\mathrm{Ch})$ at [86].

58 This is a long established principle: see Lord Kingsdown in Ramsden v. Dyson (1866) L.R. 1 H.L. 129 at 170: "If a man, under a verbal agreement with a landlord for a certain interest in land, or, what amounts to the same thing, under an expectation, created or encouraged by the landlord, that he shall have a certain interest, takes possession of such land, with the consent of the landlord, and upon the faith of such promise or expectation, with the knowledge of the landlord, and without objection by him, lays out money upon the land, a Court of equity will compel the landlord to give effect to such promise or expectation."

59 [2002] 2 P. \& C.R. 13.

60 ibid. per Sir Christopher Slade at [38].

${ }^{61}$ (1991) 62 P. \& C.R. 33. 
the question of whether it was reasonable for B to rely upon A's encouragement. B would have been entitled to a renewal of a business tenancy under the Landlord and Tenant Act 1954 but neglected to serve the requisite counter-notice in time. Notwithstanding this failure, A's agent and B had a conversation that, on balance, the majority of the Court Appeal agreed was "fairly capable of being held by the judge to have been, a promise that, unless and until told otherwise, B could rely upon getting a lease ..." ${ }^{62} \mathrm{~B}$ had previously told A's agent that he intended to do some work on the property, and after that crucial conversation he spent $£ 2,100$ on kitchen improvements and a new air scrubber. Given their reading of the conversation between the agent and B, the Court of Appeal held that A should have recognised that it was not free to resile from the agreement without first telling B. In these circumstances A was bound by proprietary estoppel to grant a new lease to B. $^{63}$

In cases where the negotiations have been expressly conducted "subject to contract" there will need to be very strong indicators indeed that A intends B to rely upon the agreement; given that both parties must be taken to know that either is free to withdraw it will not usually be unconscionable for A to deny the agreement. ${ }^{64}$ Although there have been successful estoppel claims in "subject to contract" cases, ${ }^{65}$ these will be rare. ${ }^{66}$

These "agreed interest" cases differ from the bargain cases, even though the outcome will usually be the same, namely enforcement of B's expectation. In bargain cases the assurance is for a right in return for the reliance. The reliance provides the "consideration" for the right (value being judged by A and B). In agreed interest cases the assurance is that there is a binding agreement and B's reliance prevents A from going back on this assurance. B's reliance provides the reason why $A$ is prevented from denying the agreement; the consideration for the right itself is provided by the terms of that agreement (for example, the rent agreed for a lease). B's reliance is worthy of protection because A has led B to believe

\footnotetext{
62 ibid. at 51 .

${ }^{63}$ Compare Walton Stores (Interstate) Ltd. v. Maher (1988) 164 C.L.R. 387 where the sense of urgency pervading the negotiations, and B's having returned the executed lease, put A under an obligation (especially when it knew that $\mathrm{B}$ was proceeding with the demolition) either to complete or warn B that it was having second thoughts. The appropriate response to the consequent estoppel was the enforcement of B's expectation.

${ }^{64}$ Edwin Shirley Productions Ltd. v. Workspace Management Ltd. and Others [2001] 2 E.G.L.R. 16. See also A-G of Hong Kong v. Humphries Estate [1987] A.C. 114; Gonthier v. Orange [2003] EWCA Civ. 873.

65 e.g. Salvation Army Trustee Co. Ltd. v. West Yorkshire Metropolitan County Council (1980) 41 P. \& C.R. 179.

${ }^{66}$ Although it is interesting to note the possible tension between the cases cited above at n. 64 and Gillett v. Holt [2000] 2 All E.R. 289: see Lindsay J in Gonthier v. Orange at [59] - [62].
} 
that it is safe to act on the basis that they have a binding agreement. Proportionality will usually lead to enforcement of expectations because the reliance in most cases means that $\mathrm{B}$ has "burnt his bridges" in terms of other possible projects. Further, protecting B's expectation is unlikely to be disproportionate as A will still receive the agreed consideration for the right.

At first glance, however, it sometimes looks as if the courts are too ready to assume that any act of reliance by B will enable him to enforce his expectation. JT Developments provides a good example-given B's relatively small reliance expenditure, could it really be said that B was "locked into" the project with A, and that the minimum necessary to protect B's reliance was the grant of the agreed lease? Might not a more proportionate response have been to require A to reimburse B for his wasted expenditure? These cases may, however, require a broader look at the impact of B's reliance. A's attempt to renege on the planned bargain will often be motivated by a desire to take advantage of a market which is now more favourable to him. By leading B to believe in the binding nature of the planned agreement, A will have caused B to forego the opportunity to seek a similar deal elsewhere in the previous market conditions. ${ }^{67}$ Therefore, no matter how small B's out of pocket expenditure, it may well be necessary to secure B's expectation if his reliance (in failing to take advantage of the then prevailing market conditions) is to be adequately protected.

\section{Cases not involving a bargain or agreed interest: B's expectation will be protected only if that is a proportionate means of protecting $B$ 's reliance}

As in the bargain and agreed interest cases, the extent of the right $\mathrm{B}$ acquires will be governed by proportionality, taking into account the nature and quality of A's assurances and the nature and extent of B's reliance. Proportionality has a more prominent role in these cases as the parties have not planned that $B$ should receive his expected right as part of an actual or eventual agreement. Further, B's expectation will rarely be the product of a specific assurance by A: the assurance may be vague (e.g. "You will be able to live here"; "You will get everything I have when I die"); or there may be no assurance at all. Therefore, in contrast to the two previous categories, there is no default rule in favour of protecting B's expectation.

${ }^{67}$ Wroth v. Tyler [1974] Ch. 30 shows how a rising market can impact on B. This was not an estoppel case: B sought specific performance of a contract to sell land. The contract price was $£ 6,000$, but by the time set for completion it would already have cost $\mathrm{B} £ 7,500$ to buy an equivalent property, and by the time of trial that had risen to $£ 11,500$. 
Equally, it must be emphasised that B will not necessarily be limited to claiming re-imbursement of out of pocket expenses incurred in reliance on $\mathrm{A}$. Whilst this will be the appropriate response in some cases, such as Dodsworth v. Dodsworth ${ }^{68}$ or Beale v. Harvey, ${ }^{69}$ it is important to recognise that B's reliance can extend beyond simple expenditure. ${ }^{70}$ In Habermann v. Koehler, for example, A promised B1 and B2 that they could live rent free in A's house for the remainder of A's life and that they would also have the chance to purchase the house outright. In reliance on this clear assurance, B1 and B2 moved into A's house, giving up the council house they rented and hence losing the chance to purchase it at a discount. B1 and B2 had lived in A's house as their home for over a year when A mortgaged it to $\mathrm{C}$, who later tried to remove $\mathrm{B} 1$ and $\mathrm{B} 2$. It was eventually decided that $\mathrm{B} 1$ and $\mathrm{B} 2$ had acquired a lease for A's life at a peppercorn rent. ${ }^{71}$ Whilst this case does not fit into either of the two previous categories, the clarity of A's assurance, coupled with the nature and extent of B's reliance, justified the protection of B's expectation. ${ }^{72}$ In Crabb v. Arun D.C., B's reliance consisted of losing an opportunity to reserve an easement when selling off part of his land and the only effective way to protect such reliance was to protect B's expectation of an easement over A's land. ${ }^{73}$

There is a larger element of judgment involved in determining B's right here than in the two previous categories and the courts are therefore more likely to be viewed as acting with a wide discretion. Indeed, when $\mathrm{B}$ receives a monetary award, as in Campbell v. Griffin, the amount of damages can seem to be plucked from the air: in that case, damages of $£ 35,000$ was selected but no explanation was given as to the basis for this sum. ${ }^{74}$ Similarly, in Murphy v. Burrows, the judge considered that B had lost $£ 12,000$ in wages but would have taken $£ 25,000$ as the basis of an estoppel award. $^{75}$ Nonetheless, it was in a case within this category68 (1973) 228 E.G. 1115.

69 [2003] EWCA Civ. 1883.

70 See too Gillett v. Holt [2000] 2 All E.R. 28.

71 Decision of H.H.J. Boggis: [2000] E.G.C.S. 125, The Times, 22 November 2000. The Court of Appeal had ordered a re-hearing when reversing the earlier judgment of H.H.J. Taylor: (1996) 73 P. \& C.R. 515.

72 As to the further question of whether it was also necessary for B's expectation to be protected in specie, rather than by a damages award: see below at $\mathrm{n} .105$ and text at $\mathrm{n} .117$.

${ }^{73}$ [1976] Ch. 179. Whilst Crabb is close to an "agreed interest" case, the negotiations between A and B had not yet progressed far enough to bring the case within that category: in particular, the question of payment for the envisaged easement had not been settled: see [1976] Ch. 179, $185-187$.

74 (2001) 82 P. \& C.R. (D) 23.

75 Murphy v. Burrows and Burrows [2004] EWHC 1900, a decision of Richard Sheldon Q.C. The amount of the award was obiter as the judge in fact found the estoppel claim unfounded. It is interesting, in the context of the discussion below (text from $\mathrm{n}$. 87), to note that he also said at [123] that B's expectation could be met in financial terms. 
Jennings v. Rice - that Robert Walker L.J. insisted that the courts do not possess an unfettered discretion. ${ }^{76}$ The aim of the court should be to ensure that B's right protects his reliance; whilst this is not a mechanistic process, that goal should structure the court's response. In Jennings v. Rice, Robert Walker L.J. went on to suggest that there are a wide variety of relevant factors:

... misconduct of the claimant as in $J$ Willis \& Sons v. Willis ${ }^{77}$ or particularly oppressive conduct on the part of the defendant, as in Crabb's case or Pascoe v. Turner ... the court's recognition that it cannot compel people who have fallen out to live peaceably together, so that there may be a need for a clean break; alterations in the benefactor's assets and circumstances, especially where the benefactor's assurances have been given, and the claimant's detriment has been suffered, over a long period of years; the likely effect of taxation; and (to a limited degree) the other claims (legal or moral) on the benefactor or his or her estate. No doubt there are many other factors which it may be right for the court to take into account in particular factual situations. ${ }^{78}$

It is highly questionable that a long and open-ended set of factors can provide the guidance necessary to prevent courts possessing an "unfettered discretion", particularly as the focus of the inquiry should be upon B's reasonable expectation and reliance. In so far as Robert Walker L.J.'s factors are relevant in estoppel cases they take effect not at the stage of determining what right $\mathrm{B}$ has but rather when determining what remedy is necessary to protect B's right (see Part 5 below). For example, cases that are used to support the claim that B's misconduct may be relevant in fact involve misconduct only at the remedial stage of the inquiry. In both Willis v. Willis ${ }^{79}$ and Gonthier v. Orange ${ }^{80}$ the misconduct involved the presentation of fraudulent documents at the court hearing. The effect of B's not coming to a court of equity with "clean hands" is that $\mathrm{B}$ is denied a remedy. ${ }^{81}$ Indeed, it is difficult to see why misconduct should be used as a factor in judging the appropriate response to an estoppel; there is no reason why the extent of B's right should be affected by a particular court's view of the quality of his conduct.

\footnotetext{
${ }^{76}$ [2003] 1 P. \& C.R. 100 at [43] : "It cannot be doubted that in this as in every other area of the law, the court must take a principled approach, and cannot exercise a completely unfettered discretion according to the individual judge's notion of what is fair in any particular case."

77 [1986] 1 E.G.L.R. 62.

78 [2003] 1 P. \& C.R. 100 at [52].

79 [1986] 1 E.G.L.R. 62.

80 [2003] EWCA Civ. 873.

${ }^{81}$ Hence misconduct operates, if at all, in an all or nothing fashion: see Gardner, "Remedial Discretion in Proprietary Estoppel" [1999] 115 L.Q.R. 438, at 455.
} 
As to oppressive conduct by A, it is similarly difficult to see why a general and unfocussed inquiry into A's behaviour should be relevant: indeed, the existing case-law does not provide strong support for such a contention. ${ }^{82}$ The "need for a clean break", stemming from a recognition that parties cannot be compelled to live together, needs to be treated carefully. This factor may be relevant to two points made elsewhere. First, it may be that an expectation of $\mathrm{B}$ to share property with $\mathrm{A}$ is consistent only with a personal right; hence this factor may be relevant to determining the extent of B's right as it demonstrates the limited nature of B's expectation. ${ }^{83}$ Secondly, the effect of the estoppel award on A may be in issue. For example, granting $\mathrm{B}$ a lease of a specific part of A's land may constitute a disproportionate burden on A. ${ }^{84}$ As to "alterations in [A's] assets and circumstances", it should be emphasised that the availability of a proprietary estoppel claim does not provide the courts with a justification to distribute property according to the current needs of the parties. This factor should be relevant only where B's expectation is related to A's future assets. A may, for example, promise B that he will get all of A's estate; if A then wins the lottery shortly before dying, it is very unlikely that the proportionate response to B's reliance will be to enforce B's expectation. Yet there is no need to explain this by reference to an independent factor; it rather stems from the basic goal of protecting B's reliance. In the light of that goal, it seems difficult to see the relevance of the likely effect of taxation or the presence of other claims on A or A's estate.

Therefore, as far as assessing the extent of B's right is concerned, the list of factors suggested by Robert Walker L.J. seems overly broad. It must be emphasised that a court does not have licence to conduct a general inquiry into the relative merits of the parties' conduct; in an estoppel claim, it is B's reliance on A that puts the parties before the court and the court's role must therefore be limited to recognising rights based on that reliance. Nonetheless, it is readily admitted that this group of cases will involve an element of judgment in assessing the proportionate response to the estoppel. The courts should focus squarely on the goal of protecting B's reliance, taking into account the quality of any assurances by A and the nature and extent of B's reliance: only then will they be able to give reasoned explanations providing useful guidance for future cases.

\footnotetext{
${ }^{82}$ See Gardner, ibid. at 455-457.

${ }^{83}$ See above, text from n. 40.

${ }^{84}$ See below, text at n. 114 .
} 


\section{B. Is a Property Right Necessary to Protect B's Reliance?}

\section{Basic Principles}

In order for an estoppel claim to generate a property right it must be the case that a personal right against $\mathrm{A}$ is inadequate to protect B's reliance. It will not be sufficient to show that $\mathrm{B}$ needs in specie protection, as this can be achieved by a personal right against A: for example, licences can be protected by the award of an injunction. ${ }^{85}$ Rather, the essential feature of a property right that marks it out from a personal right is exigibility: its capacity to bind third parties. Therefore, what needs to be shown is that B's reliance is not adequately protected if he has a right enforceable against $\mathrm{A}$ only. This principle is not often articulated in the case-law, although it is consistent with most actual decisions. In Pascoe v. Turner, for example, Cumming Bruce L.J. identified particular features of the case that led to B's having the fee simple: it was clear that, as a minimum, the court felt that $\mathrm{B}$ needed a right which could be asserted against potential transferees of the property. ${ }^{86}$

The simple fact of land being the subject matter of the claim is not sufficient to support a property right being given. Moreover, neither is the fact that $\mathrm{B}$ has demonstrated that his expectation of a property right should be protected ${ }^{87}$ The starting point is that B's expectation can be protected by a personal right to damages against $\mathrm{A}$, where those damages reflect the value of the property right $\mathrm{B}$ expected. B should acquire a property right only in cases where this personal right will not adequately protect his reliance.

85 Winter Garden Theatre (London) Ltd. v. Millennium Productions Ltd. [1948] A.C. 173; Verrall v. Great Yarmouth BC [1981] Q.B. 202.

${ }^{86}$ [1979] 1 W.L.R. 431 at 438-9. As to which particular property right B should have acquired in Pascoe, see below, text from n. 136.

87 This argument is not inconsistent with the principle of English law that contracts for the transfer of an interest in land are specifically enforceable and give rise to an immediate equitable interest in the transferee. A clear distinction can be drawn between cases in which A is contractually obliged to transfer an interest in land to B and those cases in which A's obligation is simply to ensure that B's reliance on A is adequately protected. Nonetheless, it may be worth noting that in Canada the law is moving away from the automatic award of specific performance of contracts to transfer an interest in land. See, for example, the remarks of Ellen MacDonald $\mathbf{J}$ in Teresa Tsang in Trust, Sino Resources (Canada) Ltd. and 786567 Ontario Ltd. v. 853908 Ontario Inc. 6 W.D.C.P. (2d) 171: "The remedy of specific performance is ... based on the fact that the real estate is regarded as unique and of particular importance to the purchaser. Specific performance is not the remedy when the land is purchased as an investment to be redeveloped and resold at a profit." See also Semelhago v. Paramedevan [1996] 2 S.C.R. 415: "Specific performance should ... not be granted as a matter of course absent evidence that the property is unique to the extent that its substitute would not be readily available." Similarly, in Australia, there are signs that a specifically enforceable contract for the sale of land to B may not always give rise to a constructive trust in B's favour: see Tanwar Enterprises Pty Ltd. v. Cauchi [2003] HCA 57, 77 A.L.J.R. 1853 at [53] and [87]. 
Hence, even in the first two categories of cases discussed above (the bargain and agreed interest cases), a property right should not necessarily be granted. As for the bargain cases, this can be seen from an examination of Yaxley v. Gotts. ${ }^{88} \mathrm{~B}$ was promised the ground floor of A's property in return for carrying out the building work required to convert the house into flats and then acting as A's managing agent. The work was completed and B had been acting as managing agent for more than two years when the dispute arose. During this time $\mathrm{B}$ had been collecting rents from the flats, paying the rent to $\mathrm{A}$, and receiving rent attributed to the ground floor flats. The judge's decision at first instance, confirmed by the Court of Appeal, was that A should execute a 99 year lease in B's favour unless, within four months, he paid B a sum equivalent to the value of such a lease. The form of this order shows that the court decided that $B$ would be adequately compensated by a personal right. If so, there should not have been a property right given in the alternative. As B's interest in the property was an investment opportunity, B had no special attachment to the land as land, and hence there was no need for B to acquire an enduring in rem right.

As for the agreed interest cases, the Canadian case of $L \& A$ Management Ltd. v. Gentra Inc. ${ }^{89}$ provides an excellent example of why a property right might not be a proportionate response to the estoppel. Unusually, this case includes an explicit consideration of whether a personal right to damages would suffice to protect B. This was due to the nature of the application: B, claiming alternatively in contract and proprietary estoppel, wished to obtain an injunction preventing A's granting a development lease of the property to $\mathrm{C}$. To succeed, B therefore had to show that a right to damages against A would provide insufficient protection. Of course, it should be noted that succeeding in the application for an injunction would not have proved that B had a property right: B's action was against $\mathrm{A}$ and hence any injunction could be seen as the in specie enforcement of a personal right. Conversely, where the denial of an injunction rests on the fact that a damages claim against $\mathrm{A}$ is adequate protection of B's reliance, then that denial must be inconsistent with B's having a property right. In $L \& A$, the judge assumed that, in the event of B's claim succeeding, whether as a matter of ordinary contract law or under proprietary estoppel, it could be satisfied with an award of damages against A. Damages could be broadly assessed taking account of B's expenditure in

${ }^{88}$ [2000] Ch. 162. See too Giumelli v. Giumelli (1999) 196 C.L.R. 101, where B's expectation was protected by a damages award secured on A's property.

89 (1999) 91 A.C.W.S. (3d) 1026 (decision of the Ontario Superior Court of Justice). 
pursuit of the project, the loss of profits, and damages for interference with economic relations. ${ }^{90} \mathrm{~B}$ had not established a sufficient attachment to the property as property: as in Yaxley, B's interest in the land was primarily as an investment opportunity. Moreover, the property was not such a unique property that there would be no similar opportunity for B. There was therefore no need to grant an injunction which would hamper the use of the property by preventing A's developing the site with C. ${ }^{91}$

\section{Relevant Factors}

It should therefore be emphasised that even if the proportionate response to B's reliance is to protect B's expectation, this does not mean that B will automatically acquire the expected property right. Rather, as shown by an examination of Yaxley v. Gotts and $L \& A$, B must show a sufficient attachment to the use of A's land as land such that a merely personal right would fail adequately to protect B's reliance. ${ }^{92}$ There are three principal factors which have been used to establish this "something more" justifying the recognition of a property right:

\section{(i) the need to support use of other land in which B has an interest;}

In the first category the claimed right benefits B's land and, in order properly to support his enduring ownership, B needs a right which is similarly enduring and capable of persisting even if A's land is transferred to C. A personal claim for damages may nonetheless suffice if $\mathrm{B}$ can use that money to obtain an adequate replacement for the right against A's land. Where this is impossible, however, money cannot make up for the loss of the enjoyment of a durable right in rem. Such cases often involve B's acquiring an easement over A's land. In Crabb v. Arun D.C., ${ }^{93}$ as a result of his reliance in selling off part of his land without reserving a right of way, B's land would be sterile without access over A's land and the Court of Appeal confirmed that $\mathrm{B}$ had an easement. In E.R. Ives Investments Ltd. v. High Lord Denning M.R. remarked that it would involve the grossest injustice not to allow B a right of access

90 ibid. at [22], per Himel J: "I am not persuaded that ordering the defendants specifically to perform their obligations under the alleged agreements is at this time, as opposed to awarding the injured party compensatory damages if the claim is successful, the only way of putting the plaintiff in the position it would have been in had the contract been performed."

91 Compare Giumelli v. Giumelli [1999] 196 C.L.R. 101: partly due to the need to avoid interference with a third party, the High Court decided to protect B's expectation by a damages award rather than a constructive trust.

92 Cf. B. Rudden, "Things as Thing and Things as Wealth" in J. Harris (ed.) Property Problems: From Genes to Pension Funds (London 1997) 147. When treated as "thing", things are made use of for what they are; when treated as wealth, things are substitutable.

93 [1976] Ch. 179. 
to his garage. ${ }^{94}$ In Ward v. Kirkland ${ }^{95}$ B put a bath and lavatory in his own property, running the drainage through A's land to a septic tank with the knowledge of A's landlord (C); on these facts Ungoed-Thomas $\mathbf{J}$ refused to grant $\mathrm{C}$ an injunction to prevent B's continuing to use the drains. One explanation of this decision is that the judge was protecting, in specie, B's easement of drainage. Alternatively, this may have been the in specie enforcement of a personal right against $C$ himself due to C's acquiescence in B's laying of the drain. Indeed, on the facts it may be that a damages award allowing B to purchase and install his own septic tank would have sufficed to protect B's reliance. ${ }^{96}$

An easement is not the only possibility: B may expect ownership of land adjoining his own. In Bibby v. Stirling, ${ }^{97} \mathrm{~B}$ had cultivated, and built a substantial greenhouse on, a strip of his neighbor's land. The Court of Appeal upheld the judge's decision that B had an equitable interest in this strip as long as B lived on the adjoining land, ${ }^{98}$ and expressly stated that this should bind A's successors. ${ }^{99}$ In Singh v. Sandhu, ${ }^{100}$ B built a garage partly on A's land. Balcombe L.J.'s judgment illustrates why it was important for B to have a property right: “... if you are encouraged to put part of your garage on somebody else's land and, indeed by way of a quid pro quo, you give up part of your land by way of exchange ... the only realistic way of fulfilling that equity is to require [A and A's successor in title] to convey to [B] ... the necessary fee simple in the part of the garage and in addition, since the garage is not much use if you cannot get to or from it, the appropriate right of way to enable it to do so". ${ }^{101}$ Hence, in both of these cases, B needed a property right capable of binding successors of A to support the use of his own land.

(ii) the need to protect B's current occupation of A's land;

The fact that $\mathrm{B}$ is occupying the property will often be a strong indication that a property right is necessary. Many well known estoppel cases illustrate this: Dillwyn v. Llewellyn (B built, and lived

94 [1967] 2 Q.B. 379 at 396. There was a difficulty in that case, glossed over by the Court of Appeal, as to whether an easement acquired by estoppel could bind C: see G. Battersby, "Informal Transactions in Land, Estoppel and Registration" (1995) 58 M.L.R. 637.

95 [1967] Ch. 194.

${ }_{96}$ Such an award would be unnecessary if $\mathrm{C}$ agreed to allow B the expected easement.

97 [1998] EWCA Civ. 994.

$98 \mathrm{~B}$ had never expected a permanent right, only one lasting as long as he lived on the adjoining land.

99 Although it is clear that this was intended to be a proprietary right, the court did not put it in legal form. It is probably best seen as a determinable fee simple.

100 unrep. May 4th 1995, C.A.

101 ibid., per Balcombe L.J. 
in, a house on A's land and acquired the fee simple); ${ }^{102}$ Pascoe v. Turner (B had been living in the house for almost 10 years and acquired the fee simple); ${ }^{103}$ Griffiths v. Williams (B had been living in A's house for most of her life and acquired a long lease $)^{104}$ and Gillett v. Holt (B had lived in the farmhouse for almost 25 years and acquired the fee simple). ${ }^{105}$ This is not only the case in residential situations: occupation of commercial premises may also support a property right. In JT Developments v. Quinn B had been running his business for five years and acquired the right to a new lease on the agreed terms; ${ }^{106}$ in Lloyd v. Dugdale B had moved his business into the property and also acquired a lease on the agreed terms. $^{107}$

Occupation is relevant even if it does not flow from reliance upon A's assurance. In many cases, B was already in occupation of the property before the relevant expectation of a right in A's property arose. ${ }^{108}$ Although it could be argued that B's occupation should only be relevant to determining the right arising through the estoppel if that occupation has occurred in reliance on B's expectation, the case-law shows an appreciation that an assessment of the nature and extent of B's post-expectation reliance cannot artificially exclude B's situation prior to that reliance. Indeed, remaining in occupation of land $\mathrm{B}$ already effectively treats as his own is often more significant and demands greater protection than simply going into occupation of a property for the first time. Preexisting occupation means that $\mathrm{B}$ has a commitment to this particular property, whether as a home or as a business. Hence a property right is more likely to be necessary adequately to protect B's reliance-disturbance of settled occupation risks causing ontological insecurity for residential occupiers (disturbing their sense of stability and identity) and commercial harm to business occupiers. ${ }^{109}$

102 (1862) 4 De G.F. \& J. 517.

103 [1979] 1 W.L.R. 431.

104 [1978] 2 E.G.L.R. 121

105 [2000] 2 All E.R. 289. See too Habermann v. Koehler [2000] E.G.C.S. 125, The Times, 22 November 2000

106 (1991) 62 P. \& C.R. 33

107 [2002] 2 P. \& C.R. 13: on the facts, B's lease did not bind C.

108 e.g. Pascoe v. Turner [1979] 1 W.L.R. 431; JT Developments v. Quinn (1991) 62 P. \& C.R. 33; Gillett v. Holt [2000] 2 All E.R. 289.

${ }^{109}$ See, e.g., Leasehold Committee, Interim Report on Tenure and Rents of Business Premises, 1949, Cmd 7760, para. 34: "A tenant with a flourishing business, or with a business which is only beginning to get on its feet, necessarily feels qualms about the results of moving. This is particularly true of retail and other traders, whose customers get used to shopping with them in a certain place ... But it applies with almost equal force to manufacturers and other businesses employing a skilled or trained labor force. Removal even within a relatively small area may involve losing valued workers, and consequent loss of production: it may interrupt carefully-organised arrangements for the supply of components, disposal of by-products, etc." 
Existing occupation will not always necessitate a property right. In Jennings v. Rice, ${ }^{110}$ there is no reason why a monetary sum would not suffice to compensate B's reliance (foregone wages), particularly as B had only been sleeping at the property to look after A. When compared with setting up home on A's land, this type of occupation is clearly less effective in establishing B's attachment to the property. Similarly in Beale v. Harvey ${ }^{111}$ the court was quite confident that B's reliance in landscaping land she mistakenly believed to be her own would be adequately protected by the receipt of money from A. The Court of Appeal did not agree that the extra strip of land had become hers: "... the detriment suffered by B by acting on A's promise or representation for so short a period is too insubstantial a detriment to make it unconscionable for A to seek to rectify its mistake at its own expense. Putting it another way, to treat what has occurred as giving $\mathrm{B}$ the right to a permanent enlargement of her garden at the expense of $\mathrm{C}$ with their smaller garden would be, in my view, quite disproportionate." 112 The result here can be contrasted with that in Bibby v. Stirling. ${ }^{113}$ The difference lies not in the nature of the occupation but rather in the degree of reliance involved-the less substantial reliance in Beale did not suffice to establish a sufficient attachment between $\mathrm{B}$ and the property.

Finally, a particular problem which may arise in cases where A and B share occupation of A's land should be noted. Within a sharing arrangement, it may be possible to argue that $\mathrm{B}$ should have a right to exclusive possession of a specific part of A's land. However, recognising that $\mathrm{B}$ has such a property right will often have a disproportionate impact upon A. A lease of part only of a whole, particularly if it involves the sharing of common parts, will have a significant impact upon the value of A's property and hence may be a disproportionate response to B's reliance. ${ }^{114}$ This can be illustrated from the factual background to Baker v. Baker. ${ }^{115} \mathrm{~B}$ had contributed almost $£ 34,000$ towards the purchase of a house by A1 and A2. B's claim to a beneficial share failed at first instance and was not pursued on appeal. In the Court of Appeal, Dillon L.J. explained that "the greatest interest in the property that the parties

${ }^{110}$ [2003] 1 P. \& C.R. 100.

111 [2003] EWCA Civ. 1883.

112 per Peter Gibson L.J., ibid. at [39].

113 [1998] EWCA Civ. 994.

114 The courts frequently assert that the response to the proprietary estoppel cannot have an oppressive or excessive effect on A: see e.g. Griffiths v. Williams [1978] 2 E.G.L.R. 121; Dodsworth v. Dodsworth (1973) 228 E.G. 1115; Deane J. in Commonwealth of Australia v. Verwayen (1990) 170 C.L.R. 394 at 443; Giumelli v. Giumelli (1999) 196 C.L.R. 101 at [49]. Note too the discussion of Crabb v. Arun D.C. in Bright and McFarlane, "Personal Liability in Proprietary Estoppel" [2005] Conv. 14 at 27-28.

115 [1993] 2 F.L.R. 247. 
envisaged ... [B's] having was the right, living as part of the family, to occupy the granny room rent-free for the rest of his life making the contributions to household expenses which I have indicated." 116 If, however, this kind of arrangement is viewed as a lease of the granny room it will make it very difficult for A1 and A2 also to enjoy the property. Given the breakdown in their relationship, B's presence would prevent A1 and A2's enjoying their land in specie. B's occupation under a lease would also make it very difficult for A1 and A2 to realise the value of their house on a sale as it will be almost impossible to sell a property which is not designed for multiple units of occupation and yet is partly tenanted. The result is that a lease of part only of a whole will often be a disproportionate response.

(iii) the need to compensate $B$ for giving up an opportunity to acquire a property right.

Where B's reliance takes the form of losing the opportunity to acquire an alternative property right, then protecting that reliance may well require that B gain a property right in A's land. Hence, in several cases, courts have taken note of the fact that B's reliance has caused him to forego alternative opportunities to acquire a property right. In both residential and commercial cases, this factor is often coupled with, and can lend weight to, the need to protect B's occupation. ${ }^{117}$ In Habermann v. Koehler, B1 and B2's act of reliance included giving up their existing flat which they would soon have been able to buy at a discount under the right to buy legislation; ${ }^{118}$ in Gillett v. Holt $\mathrm{B}$ had lost his foothold in the property market by selling his own small house in reliance upon A's assurances. ${ }^{119}$ Similarly, in Lloyd v. Dugdale, B's reliance expenditure meant that B was "locked in" to A's property and had lost the chance to secure business premises elsewhere. ${ }^{120}$

\section{Proprietary Overkill?}

As mentioned in the introduction, courts have not always adopted a conservative approach towards the recognition of property rights - there are cases in which the courts have recognised property rights in $\mathrm{B}$ when a personal right would do. It may be that this is in part a hangover from the days when it was simply assumed that

\footnotetext{
116 ibid. at 250 . In this case B had already left the property because of the breakdown in the family relationship and there was no question of his enjoying any occupational right in specie.

117 Equally, it can be coupled with the need to support the use of other land in which B has an interest, as in Crabb v. Arun D.C. [1976] Ch. 179.

118 Decision of H.H.J. Boggis: [2000] E.G.C.S. 125, The Times, 22 November 2000.

${ }^{119}$ [2000] 2 All E.R. 289.

120 [2002] 2 P. \& C.R. 13, per Sir Christopher Slade at [38].
} 
a successful proprietary estoppel claim had to lead to property rights. There is also a tendency to underestimate the power of a personal right. In Liverpool v. Walton, ${ }^{121}$ for example, A and B had entered into an agreement for a 999 year lease on the basis of which B spent substantial amounts of time and money satisfying the conditions precedent to the grant of the lease itself. There was some doubt as to whether one of the clauses made the agreement void for uncertainty. On the assumption that this was the case, Neuberger J. thought that the agreement would nonetheless be enforceable in specie via estoppel, working on a model of estoppel that normally enforces expectations unless this is unfair or oppressive to A. ${ }^{122}$ As to the argument that sometimes $\mathrm{B}$ has to make do with money, he considered that this was only the case if a proprietary right would have exceeded B's expectation. ${ }^{123}$ This is of course hard to reconcile with the later Court of Appeal decision in Jennings v. Rice. Further, the reasons given for a property right being necessary are not persuasive. They focus on the inadequacy of a damages award, ${ }^{124}$ but assume that such an award would be insufficient to deprive A of benefits received as a result of B's expenditure or to secure the profits B expected. Whilst this is true if the award were to consist only of reimbursement of B's expenditure, a more imaginative approach to damages could make allowance for each of these factors. ${ }^{125}$ Again, it must be emphasised that damages need not be confined to compensating B's out of pocket expenditure: fully protecting B's reliance may well require that the damages award also takes account of opportunities B has lost as a result of that reliance.

It is perhaps understandable that when the instant case does not involve a transfer to a third party, a court might grant B a property right for reasons of convenience. ${ }^{126}$ Nonetheless, the need for proportionality demands that any property right must be justified by necessity rather than convenience. Further, the need for consistency means that the question of whether $\mathrm{B}$ acquires a property right or only a personal right cannot depend on whether the instant case happens to involve a transfer of A's land to C.

${ }^{121}$ unrep., 25th July 2001, Ch.

122 ibid. at [82].

23 ibid. at [80].

124 ibid. at [84].

125 In both Giumelli v. Giumelli [1999] 196 C.L.R. 101 and L\&A Management Services Ltd. v. Gentra Inc. (1999) 91 A.C.W.S. (3d) 1026 the court accepted that damages awards reflecting B's expectation could be made: see above, text from n. 89 .

${ }^{126}$ See e.g. Holiday Inns v. Broadhead (1974) 232 E.G. 951. In attempting to allow B the monetary value of his expectation, Goff J. ordered that A should hold his reversion on trust for sale for $\mathrm{A}$ and $\mathrm{B}$ in equal shares. It seems that B acquired this property right simply because it was a more convenient route to B's receiving the necessary monetary award. 
This must be borne in mind when examining the cases in which $\mathrm{B}$ acquires a lien as a result of the estoppel. In recognising B's right to $£ 35,000$ in Campbell v. Griffin ${ }^{127}$ the Court of Appeal, without explanation, stated that this sum was charged on the property and would take priority over the Council's statutory charge to cover the costs of residential care. The recognition of a lien must be justified in the same manner as other property rights, yet there was no discussion of why a simple monetary award would not suffice. ${ }^{128}$ The result in Campbell can be compared with that in Jennings v. Rice: in the latter case, B was acknowledged to have simply an unsecured personal right to payment from the estate. The suspicion must be that it was the subsequent intervention of a third party, in the form of the Council's statutory charge to cover residential care costs, which led to the finding of a lien in Campbell. However, a more principled approach is clearly necessary: liens, if they arise, do so when the facts of estoppel are established; how matters turn out later is not relevant. If a lien is to arise, then a court must explain why it is necessary in order to protect B's reliance.

Liens perform the function of protecting a right to be paid by giving a proprietary right which confers priority and durability. It is not possible to identify a common theme to the situations in which liens can be found and there is no agreement as to their theoretical basis. ${ }^{129}$ It may simply have to be conceded that the courts have recognised that certain fact patterns will generate liens: e.g. the right to payment upon the sale of real property (the unpaid vendor's lien); the right to payment for legal services on the recovery of property (the solicitor's lien); and the insurer's lien over money received from a wrongdoer to which the insurer is entitled by subrogation. The question then becomes one of whether particular fact situations within proprietary estoppel are capable of supporting a lien.

Existing case law does not assist on this. Those cases that do involve liens to secure payment do not explain why the lien exists; the closest to an explanation is the observation by Robert Walker L.J. in Jennings that where B's detriment consists of expenditure on improvements an equitable charge may be sufficient to satisfy the

127 (2001) EWCA Civ. 990, (2001) 82 P. \& C.R. (D) 23.

128 Similarly, no explanation was given for the charge over A's property ordered by the High Court in Giumelli v. Giumelli [1999] 196 C.L.R. 101. This is strange as the High Court rejected the contention that A's land was held on constructive trust for B, emphasizing at 113 that "[b]efore a constructive trust is imposed, the court should first decide whether, having regard to the issues in the litigation, there is an appropriate equitable remedy which falls short of the imposition of a trust"; yet there was no consideration of why a lien was more appropriate than a simple award of damages. See also the failure to explain why a lien was thought appropriate in Murphy v. Burrows and Burrows [2004] EWHC 1600 at [124] and Cobbe v. Yeoman's Row Management Ltd. [2005] EWHC 266 (Ch) at [136].

129 See Halsbury's Laws of England, vol. 28, para. 754. 
equity. ${ }^{130}$ It may be that, where B's reliance has enhanced the value of A's property, this reliance is particularly worthy of additional protection. ${ }^{131}$ Certainly, it is hard to see why, unless there is such a close link between B's reliance and A's property, B should not be restricted to the usual range of unsecured rights or why his right should be capable of prevailing against C. ${ }^{132}$ This suggested explanation is not, however, borne out by the case-law: a charge existed in Campbell v. Griffin even though B's reliance involved caring for A, yet there was no charge in Dodsworth v. Dodsworth ${ }^{133}$ although B had spent time and money improving A's property.

It may well be that liens were granted in cases such as Campbell v. Griffin and Unity Joint Stock Mutual Banking Association v. King $^{134}$ as a result of a mistaken assumption that proprietary estoppel must lead to property rights. On this view, if it does not create proprietary user rights then an estoppel must create a lien supporting a right to monetary compensation. Of course, this view is clearly inconsistent with cases such as Jennings v. Rice and Dodsworth v. Dodsworth, and the reasoning in Beale v. Harvey; it is also deeply unattractive as a doctrinal argument. ${ }^{135}$ A proportionate response to estoppel may well be for $\mathrm{B}$ to have a personal right: where that personal right is a right to damages it must not be assumed that it will be secured by a charge on A's land.

\section{Which property right?}

It must be emphasised that proportionality in protecting B's reliance will determine not only whether B acquires a property right but also what particular property right $\mathrm{B}$ gains: that property right must not exceed the minimum necessary to protect B's reliance. Pascoe v. Turner ${ }^{136}$ may provide an example of the dangers of overlooking this point. The court's determination to ensure that B's occupation of her home would be secure may be thought sufficient to justify the acquisition of a property right. Yet was it really necessary for B to acquire the fee simple? Might a lease for life, as in Habermann v. Koehler or Griffiths v. Williams, have been a more

${ }^{130}$ [2003] 1 P. \& C.R. 100 at [51].

131 As in Cobbe v. Yeoman's Row Management Ltd. [2005] EWHC 266 (Ch).

132 Although there is no consensus on why liens are given, it is the case that they are only found when there is a close link between B's claim and A's property. With the unpaid vendor's lien, A has only acquired the property from B on the contractual promise of payment. With the solicitor's lien, B is entitled to a lien over A's property as the fruits of his time and effort. With the insurer's lien, the property is a fund of money to which B is entitled.

133 (1973) 228 E.G. 1115.

134 (1858) 25 Beav. 72.

135 See McFarlane, "Proprietary Estoppel and Third Parties after the Land Registration Act 2002”' [2003] C.L.J. 661, 688-693.

136 [1979] 1 W.L.R. 431. 
proportionate response? ${ }^{137}$ In particular, it should not be assumed that, just because $\mathrm{B}$ needs $a$ property right, that right must be the property right B expected. In Ottey v. Grundy, ${ }^{138}$ for example, B's expectation was of a life interest in A's houseboat as well as full ownership of a flat in Jamaica: B was found to have a property right only in the flat.

\section{Can B's property right change over time?}

It is clear that the extent of any right $B$ acquires as a result of proprietary estoppel may vary over time. The usual case will be that B's right grows in order to protect B's continuing reliance: hence, after initially acquiring a personal right, the further reliance may justify B's gaining a property right. ${ }^{139}$ The rarer case is where B's right seems to diminish over time. In Sledmore v. Dalby, ${ }^{140}$ B's understanding was that he could stay in A's house. By the time of the hearing, B had property elsewhere and was using the house only one or two nights a week, whereas A was vulnerable and likely to lose her present housing. One interpretation of the court's decision to allow A's action for possession is that it was a response to the changing circumstances which led to A's having a more pressing need for occupation than B. ${ }^{141}$ On the view put forward in this article, however, a general inquiry into the relative needs of the parties should form no part of the court's role when determining the extent of the right $\mathrm{B}$ acquires through proprietary estoppel: rather, only those factors relevant to protecting B's reliance should be considered.

In Sledmore, B had spent money on improving the property over a three year period and had then enjoyed a further fifteen years of rent-free accommodation. Given the limited nature of the detriment incurred by B's initial reliance, a right for B to remain for life would be disproportionate. The best explanation is that B had a right which had already been wholly satisfied: that is a right to occupy for a period shorter than that which elapsed between his reliance and A's action for possession. ${ }^{142}$ Therefore, whilst it is correct that A may not have been able to recover possession had

\footnotetext{
137 The court rejected a lease on the basis that A could exploit the landlord-tenant relationship to harass B. Given there are other means by which to address such a risk (e.g. an injunction) it is highly doubtful that it justified A's being permanently deprived of the property.

138 [2003] EWCA Civ. 1176.

139 For example, continuing occupation by B may constitute a sufficient attachment to the land to justify a property right: the case may move from Beale v. Harvey [2003] EWCA Civ. 1883 to Bibby v. Stirling [1998] EWCA Civ. 994.

140 (1996) 72 P. \& C.R. 196.

${ }^{141}$ See e.g. Adams, "Is Equitable Estoppel a Wasting Asset?" [1997] Conv. 458 at 463. See too Rotherham, Proprietary Remedies in Context, p. 308

${ }^{142}$ See McFarlane, "Proprietary Estoppel and Third Parties after the Land Registration Act 2002” [2003] C.L.J. 661 at 681-683.
} 
the case been brought at an earlier date, this is not because the later change in the parties' needs altered B's right but rather because B's right to stay was always limited in time. As Roch L.J. put it, "the minimum equity to do justice to [B] on the facts of this case was an equity which has now expired." 143

Sledmore v. Dalby can thus be seen as a case in which B acquired a time-limited right which had expired by the time of the court's decision. The crucial question, however, is whether B can acquire a property right which is later lost, not due to any inherent time-limit, but rather due to a change in circumstances. If property rights can be lost, it can only be because of changes that affect one of the factors which meant that a property right was necessary to protect B's reliance in the first place. If, for example, after relying on A's assurance that his home was hers, the mistress in Pascoe v. Turner had won the lottery and purchased a new home, could it be said that she no longer had a sufficient attachment to A's property to justify a property right in it?

The suggestion that property rights might diminish or be lost over time is unappealing. It would give rise to many practical problems, especially in considering the effect of B's right on C. Conceptually, it is difficult to see how B can lose a property right without any overt act on her part, such as a transfer or abandonment. But most importantly, the suggestion that B could lose a property right by a change in circumstances is inconsistent with the purpose of proprietary estoppel. The doctrine aims to protect the reliance B has incurred: therefore, if, by her past acts, B established a sufficient attachment to the property to warrant a property right, that right should not be lost, and A should not benefit, by her later fortune in finding a new home. The need for proportionality demands that the particular property right is justified by the facts as they exist at the time of completion of the acts of reliance. There is no discretion to vary property rights at a later date. Therefore, once $\mathrm{B}$ has done enough to establish a property right that right should remain. This provides a further reason why a court should be cautious before deciding that $\mathrm{B}$ has acquired a property right. However, as will be seen in Part 5, a change in circumstances can be taken into account by the court when giving effect to B's right.

\section{REMEDIES}

Having determined the extent of B's right, the court will attempt to fashion an order which gives best effect to that right, given the 143 (1996) 72 P. \& C.R. 196 at 204-205. 
prevailing circumstances at the time the order is made. A wide variety of factors come into play at this stage. The crucial point is that, when applied at the remedial stage, these considerations are not unique to proprietary estoppel: rather, they will be relevant no matter how B's right arose. Confusion stems from the fact that, in proprietary estoppel cases, there is often a blurring of the two distinct stages constituted by determining the extent of B's right and then granting a remedy to give effect to it. ${ }^{144}$ This leads to an exaggeration of the discretion inherent at the first stage and obscures the fact that the extent of B's right can be determined by the basic goal of protecting B's reliance.

Of the factors identified by Robert Walker L.J. in Jennings v. Rice, ${ }^{145}$ a number are relevant at the remedial stage, whether B's right arose through estoppel or some other means. For example, specific performance of a contractual right of $\mathrm{B}$ may be denied as a result of alterations in A's needs and circumstances, ${ }^{146}$ or due to the position of a third party. ${ }^{147}$ Equally, the need for a clean break may be relevant: if $\mathrm{B}$ has a contractual licence to share a house with $\mathrm{A}$, yet the two have fallen out, then this may lead to B's being awarded damages rather than an in specie remedy. ${ }^{148}$ If $\mathrm{B}$ has a beneficial share of the property, for example under a resulting trust, the state of his relations with $\mathrm{A}$, his fellow co-owner, can be taken into account by the court in exercising its powers under section 14 of the Trusts of Land and Appointment of Trustees Act 1996. Equally, it is possible that the likely effect of taxation may reduce the effectiveness of a particular remedy in giving effect to B's right, and hence lead the court to adopt a different solution. ${ }^{149}$ As can be seen, the relevance of these factors at the remedial stage is not unique to proprietary estoppel.

It is clear that the court will have a remedial discretion in deciding whether to give in specie effect to a personal right or to a property right governed by the 1996 Act. Further, in Wrotham Park Estate Co. Ltd. v. Parkside Homes Ltd., ${ }^{150}$ a party was refused in specie enforcement of a restrictive covenant where an injunction

\footnotetext{
${ }^{144}$ Birks has noted (e.g. in "Proprietary Rights as Remedies" in P. Birks (ed.), Frontiers of Liability (Oxford 1994), at p. 214) that a careless use of the word "remedy" can cause such confusion.

145 [2003] 1 P. \& C.R. 100 at [52]: see above, text at n. 78.

146 Patel v. Ali [1984] Ch. 283.

147 Wroth v. Tyler [1974] Ch. 30.

148 Thompson v. Park [1944] K.B. 408: per Goddard L.J. at 409: "the court cannot specifically enforce an agreement for two people to live peaceably under the same roof."

149 Taxation consequences can be taken into account by the court when exercising its powers under the Trusts of Land and Appointment of Trustees Act 1996 or under the Variation of Trusts Act 1958. For example, where B has acquired a beneficial life interest he may wish to avoid the Inheritance Tax consequences of such an interest by terminating it in favour of receiving a capital lump sum.

150 [1974] 1 W.L.R. 798.
} 
would have been unduly wasteful and caused prejudice to third parties. There is, however, little room for such discretion if the court decides that $\mathrm{B}$ has acquired a freehold, lease or easement as a result of the estoppel. If such a right is necessary to protect B's reliance, it is hard to see how a court could be justified in forcing $B$ to accept a monetary substitute for that right. This absence of remedial flexibility provides a further reason why courts should be cautious before deciding that a freehold, lease or easement is necessary to protect B's reliance.

Where $\mathrm{B}$ has a property right but the land has been transferred to $\mathrm{C}$, who is not bound by that right, then in specie enforcement will obviously be barred. In most cases, B will then have to fall back on A's persisting personal liability by bringing a claim for damages. Where B was beneficially entitled to the property, either wholly or in part, then B will have the option of tracing that entitlement into the proceeds of any transfer from A to C. ${ }^{151}$

\section{CONCLUSION}

The main purpose of this article has been to examine when a proprietary estoppel claim should lead to the acquisition of a property right. To do so, it has been necessary to set out basic principles which can be used to determine the nature and extent of rights acquired by proprietary estoppel. These principles flow from the submission that the goal of proprietary estoppel is to protect reliance on an expectation, for which $\mathrm{A}$ is responsible, that $\mathrm{B}$ has or will acquire a right in relation to land owned by $\mathrm{A}$.

One important theme has been that the wide discretion which apparently characterises proprietary estoppel has been exaggerated. When determining whether $\mathrm{B}$ has a right through estoppel, the court has the general discretion inherent in its equitable jurisdiction and can, for example, deny B's claim due to a lack of "clean hands". When assessing the nature and extent of B's right, any flexibility the court possesses is inherent in, and constrained by, the need to do the minimum necessary adequately to protect B's reliance. Finally, when deciding on the appropriate remedy to give effect to B's right, the court can take into account the same wide variety of factors that are relevant whenever a court attempts to fashion a remedy. There is thus no special discretion which is unique to proprietary estoppel claims. Hence there is no need to assume that because the response to proprietary estoppel is not

${ }^{151}$ This is the best explanation of Wayling v. Jones (1993) 69 P. \& C.R. 170: see Bright and McFarlane, "Personal Liability in Proprietary Estoppel" [2005] Conv. 14 at 19-20. 
always moored to B's expectation it is therefore free to float on an open sea of discretion.

A further theme has been that the courts must take more care in justifying a finding that $\mathrm{B}$ has acquired a property right. It has been contended that $\mathrm{B}$ will have a personal right against $\mathrm{A}$ which will persist after any transfer of the property by A. Further, this right will not just entitle $B$ to reimbursement of out of pocket expenses but will rather extend to allowing $\mathrm{B}$ whatever damages are necessary to protect his reliance: in some cases, these damages should be designed to give effect to B's expectation. Therefore, B should only acquire a property right where the possibility of binding future owners of A's land is necessary to ensure that B's reliance is adequately protected. This stands in contrast to the Law Commission's preferred interpretation of section 116(a) of the Land Registration Act 2002, under which B's estoppel claim is always capable of binding $\mathrm{C}$. Where B's reliance can be adequately protected by means of a purely personal right, it will be unnecessary and disproportionate for B's claim to be capable of binding a transferee of the registered land.

Finally, it should be emphasised that an inquiry into when proprietary estoppel gives rise to property rights should not be viewed in isolation. There is a wider question as to whether, and when, non-consensual sources of rights, such as unjust enrichment or wrongs, should give rise to property rights. The current inquiry has been confined to proprietary estoppel and has attempted to show first, that it is a non-consensual source of rights; secondly, that it clearly is capable of giving rise to property rights; and finally that it is possible to suggest principles regulating when such rights should arise. It may be that the approach suggested here can also be of use when investigating the ability of other nonconsensual sources of rights to give rise to property rights. 